\title{
Innovation, Diffusion, Growth and the Environment: Taking Stock and Charting New Directions
}

\author{
Mare Sarr $^{1}$ - Joëlle Noailly ${ }^{2}$
}

Published online: 26 January 2017

(C) Springer Science+Business Media Dordrecht 2016

\begin{abstract}
The objective of this article is to provide a succinct review of the main developments in the field of research on the economics of growth, innovation, diffusion and the environment. We focus on the last fifteen to twenty years of scientific advances in the field as this corresponds to: $(i)$ the consensus on the theoretical side on endogenous economic growth modelling, and (ii) the growing empirical work on innovation and diffusion due to the development of patent data. As very good reviews already exist in the literature, we only provide a brief and non-exhaustive discussion aiming at taking stock of some recent developments and charting new issues for a future research agenda.
\end{abstract}

Keywords Technological change $\cdot$ Innovation $\cdot$ Diffusion $\cdot$ Growth $\cdot$ Patents

JEL Classification $\mathrm{O} 33 \cdot \mathrm{O} 34 \cdot \mathrm{Q} 55$

\section{Introduction}

As early as in the nineteenth century, classical economists Thomas Malthus and David Ricardo had raised the question of the sustainability of economic growth beyond a certain limit given the finiteness and scarcity of resources. Fast forward, in the 1970s, a similar argument based on population growth, diminishing returns to labor and fixed supply of land was made by the Club of Rome in its publication "The Limits to Growth" (Meadows et al. 1972). The authors argued that given a growing world population and finite resources, human society will eventually

Joëlle Noailly

joelle.noailly@graduateinstitute.ch

Mare Sarr

mare.sarr@uct.ac.za

1 School of Economics, University of Cape Town, Economics Building, Private Bag, Rondebosch 7701, South Africa

2 Center for International Environmental Studies, Graduate Institute of International and Development Studies, Geneva, Switzerland 
run out of resources, which will put a physical limit to growth. One major weakness of the limits to growth argument, however, is that it was based on models that ignore any feedback within the economy, or any technological response to increasing scarcities. Those models are at odds with the history of the industrialization of western economies, which demonstrates substantial amounts of technological change and productivity improvements in the face of resource depletion. Without technological progress indeed, additional units of capital would yield a decreasing marginal product as natural resources deplete. However, as Nordhaus et al. (1992) argue, technological progress can, under some conditions, overcome resource constraints and diminishing returns to capital. In fact, the increasing scarcity of a resource may provide incentives to search for new technologies ("backstop technologies") that will rely upon less scarce inputs (Dasgupta and Heal 1974). That is, investments in technological change will compensate for increasing scarcity, and move the economy toward techniques that are less reliant upon increasingly scarce natural resources. Under this optimistic and broadly accepted view, many economists, climate scientists and policy makers alike (e.g., the Intergovernmental Panel on Climate Change (Metz et al. 2007) and the Stern Review on the Economics of Climate Change (Stern et al. 2006)) express their belief that innovations are not only crucial for development; they also have the potential to direct an economy towards a greener and more sustainable future (Bretschger 2015).

Over the last decades, economic models linking the engine of growth-namely innovation and diffusion - and the environment, have considerably evolved. Twenty years ago, technology was still often modelled as an exogeneous and autonomous process and empirical work on measuring technical progress, as initiated by Griliches (1990), was still in its infancy. Much has been achieved over this period and the objective of this article is to provide a succinct overview of the main developments in this field of research. As very good reviews already exist in the literature (Jaffe et al. 2003; Popp et al. 2009; Popp 2015), we only provide here a brief and non-exhaustive overview aiming at taking stock of the current literature and charting issues for a future research agenda. In Sect. 2, we briefly review some of the main theoretical developments. In Sect. 3, we provide a summary of the empirical work highlighting current gaps in metrics and knowledge. Section 4 concludes.

\section{The Theory of Growth and the Environment: The Role of Technological Change in Climate Policy}

\subsection{Induced Innovation Takes Centre Stage}

Innovations have become central to climate change policy discourse (Metz et al. 2007), and are increasingly regarded as a solution to overcome the conundrum between economic development and environment protection (Aronsson et al. 2010; Gerlagh and Kuik 2014; Grubb 2000; Hübler et al. 2012; Bretschger 2015). Technological progress is indeed often perceived as a silver bullet that has the capacity to, not only spur economic growth but also reduce environmental externalities, thus enabling countries to produce more while economizing on resources and energy. To overcome the trade-off between development and environmental protection, two policy instruments addressing the two prevailing market failures (the environmental externalities and the public good nature of innovation) are usually prescribed. The former involves the pricing of carbon to induce emitters to internalize environmental externalities through carbon taxation; while the latter involves the provision of incentive mechanisms that include direct subsidies to $\mathrm{R} \& \mathrm{D}$, cost savings from tax or permit avoidance, prizes and 
patents. State intervention plays therefore a critical role in providing the correct incentives for optimal investments in R\&D and innovation, and the correct incentives for abating GHG emissions. However, what the actual mix of regulatory instruments should contain to address these dual market failures is not straightforward. Although the theoretical literature often points to the importance of pricing carbon through a carbon tax, $R \& D$ subsidies prove to be the more popular instrument in practice because more politically acceptable (Popp 2006). In a recent paper, Acemoglu et al. (2012a) analyze the impact of different types of environmental regulations on the direction of technical change. They conclude that a two-prong strategy based on carbon taxation and research subsidies is superior to a policy based solely on a carbon tax. This study corroborates findings by Popp (2006) that combining optimal carbon tax and R\&D subsidies yields the largest welfare gain compared with either separate policy.

Whether technology policy is needed in addition to carbon pricing to tackle climate change efficiently has been a subject for debate among economists (Kalkuhl et al. 2012). Proponents of such intervention argue that an additional instrument is required to address the additional market failure due to innovation spillovers (Fischer and Preonas 2010). Its critics however, hold the view that technology-unspecific instruments such as generic patents and research subsidies will provide sufficient incentives for innovations in the energy sector (Nordhaus 2011), while obviating the possible rent-seeking, transaction costs and information problems that would result from technology-specific policies.

In any eventuality, in climate change policy models, government is typically able to alter the direction of technological change toward carbon-saving technologies by inducing policies [the so-called induced technological change (ITC)] that seek to align technological change with improved environmental quality (Gillingham et al. 2008) through mainly three channels: energy prices (Jacoby et al. 2006), learning-by-doing (Goulder and Mathai 2000), or research and development (R\&D) activities (Goulder and Mathai 2000; Smulders and Nooij 2003; Acemoglu et al. 2012a). The price-based channel implies that an increase in relative energy prices may spur innovation by providing firms the incentive to substitute more expensive inputs (e.g., energy) in accordance with the Hicks-induced innovation hypothesis. The learning-by-doing (LBD) channel fosters innovation by enabling reductions in production costs through accumulated production experience. Learning-by-doing proves to be a popular channel for endogenizing technological change because of its tractability, particularly in disaggregated "bottom-up" models; this, despite being often modelled in an ad hoc and reduced-form fashion, or despite ignoring the general equilibrium effects of learning induced productivity improvements (Sue Wing 2001). Finally, the R\&D channel stimulates innovation through investment (accumulation) in knowledge capital stock which alters the rate and direction of technological change (Popp 2004, 2006a; Sue Wing 2003; Buonanno et al. 2003; Smulders and Nooij 2003; Goulder and Mathai 2000; Goulder and Schneider 1999; Grubb et al. 1995). This contrasts sharply with exogenous assumptions about the rate of overall and carbon-saving technological change, which are unresponsive to policy (Gillingham et al. 2008).

The move towards endogenizing technological change (via environmental policies) is, in our view, one of the major advances in this field over the past two decades. It builds on advances in growth theory (Romer 1990; Grossman and Helpman 1991; Aghion and Howitt 1992) that provide mechanisms through which economic growth is spurred by endogenous technological progress resulting from investment in research and development (R\&D) or accumulated knowledge rather than by an exogenous process. In those models (both Romerian and Schumpeterian), the direction and extent of technological change is driven by incentive mechanisms that enable the appropriation of innovation rents. Two key distinctive features characterize induced innovation models in climate policy: $(i)$ the role of substitution or com- 
plementarity between investment in energy-saving R\&D (clean technology) and investment in other R\&D sectors (dirty technology); and (ii) the extent and role of spillover effects in $R \& D$. The substitution assumption typically results in crowding out effects that may in some cases cancel the benefits of environmental policy (Nordhaus 2002), while the assumption of complementarity enables firms to ignore the usual trade-off between output generation and environmental protection because greater savings can be achieved while increasing output through greater productivity (Buonanno et al. 2003). Interestingly, recent developments in the empirical literature (Verdolini et al. 2016) provide some evidence suggesting strong complementarity of investments in different generation technologies (renewable vs. fossil electricity generation capacity) for a successful decarbonization process.

The presence of spillovers signals the existence of market imperfection in the production of knowledge in that the social returns to $R \& D$ are relatively high with respect to the private returns. Individual firms are typically unable to appropriate the social value of their innovation, which reduces their incentive to invest in $R \& D$. On the other hand, the presence of spillovers tends to reduce the cost of environmental policy because it partially corrects the R\&D market imperfection (Gillingham et al. 2008).

\subsection{Effect of ITC on the Cost of Environmental Policy}

That induced technical change reduces the cost of environmental policy through a decrease in the marginal cost of abatement has been one the main findings of the literature. Much of the debates focused initially on shedding light on the magnitude of the cost savings resulting from induced technological change which has ranged from large to insignificant (Popp 2004, 2006a, b). It has been shown that this magnitude critically depends on the opportunity cost of investing in energy efficient or clean technologies as opposed to investing in other potentially productivity-enhancing (albeit dirty) technologies (Sue Wing 2003; Nordhaus 2002; Popp 2004, 2006a, b). However the early consensus about the cost-saving effect of ITC has been recently questioned as it appears that policy interventions that promote climate-friendly technological change may yield unexpected outcomes, be they in the form of increased cost of climate policy or unintended consequences such as the so-called green paradox.

Recent studies suggest that the shift in the marginal abatement cost (MAC) resulting from technological change, need not translate in a reduction in the MAC. If indeed, the usual assumption that environmental policy necessarily reduces the marginal cost of abatement is relaxed (Perino and Requate 2012; Brechet and Meunier 2014; Smulders and Di Maria 2012), the effect of innovation through environmental policy may be to increase rather than to reduce pollution. Smulders and Di Maria (2012) argue that as new technology is developed, technological change may instead increase the productivity of polluting inputs, and thus the marginal abatement costs. To the very least, changes in technologies induced by environmental regulation may (partially) offset the benefits of the policy itself, and as a result ITC potentially makes environmental policy less effective or more costly (Smulders and Di Maria 2012). This would typically be the case if environmental regulation incentivizes innovation in dirty technologies since they have the effect of increasing the marginal abatement cost and ultimately the total cost of abatement and the total emissions levels. For example, while numerous technological breakthroughs (e.g., internal combustion engines, petrochemical plastics and fertilizers, or intercontinental flights) did enhance firms' profits and social welfare, they also resulted in unprecedented increases in pollution because of their over-reliance on fossil fuels.

Another channel that leads to environmental cost increase pertains to the crowding-out effect of climate policy on innovation mentioned earlier. In fact, while policy intervention is 
likely to induce an increase in R\&D investment in energy-intensive industries, overall innovation could be depressed because of reduced $R \& D$ investment in other industries (Smulders and Nooij 2003).

Finally, the implementation of an environmental policy aimed at encouraging renewable resources may have unintended consequences, one of which is the green paradox, a phenomenon that has attracted much attention in recent years. By acting as a backstop technology for exhaustible resources such as fossil fuel, environmental policy may have countervailing effects: it could precipitate the end of exploitation of the fossil fuel in question but could also accelerate its extraction (Sinn 2008). The former effect is welfare-increasing with respect to the environment while the latter is welfare-reducing. Which effect dominates is a priori ambiguous. A green paradox occurs whenever the latter effect dominates (Ploeg and Withagen 2012; Eichner and Pethig 2011); for instance, when the introduction of a subsidy on green technology induces an overall increase in harmful CO2 emissions.

Thus, as noted by Smulders and Di Maria (2012), ambitious environmental policy efforts that rely on significant shifts in the existing technological paradigm need to be complemented by carefully designed measures to ensure that the incentives that emerge for investors are not misaligned relative to those of the social planner.

\subsection{Effect of ITC on the Path of Environmental Policy and Path Dependence}

Besides the question of the cost of climate policy, the implications of induced innovation for optimal climate policy (optimal path of environmental tax and abatement effort) has attracted much attention, but little consensus. The diverging conclusions on this issue are due to two crucial assumptions: $(i)$ the assumption of perfection versus imperfection of the knowledge market; and ( $i$ i) the form of induced innovation, i.e., R\&D-based or learning-by-doing-based. In the case of a carbon tax, Goulder and Mathai (2000) show that, in the absence of knowledge market imperfection (i.e., no R\&D spillover), the path of carbon tax required given induced technological change is lower than the path resulting from an exogenous technical change. In the presence of knowledge market imperfection however, the carbon tax level should be greater than that originating from an exogenous technical change. In particular, the carbon tax should be set above the Pigouvian tax (Gerlagh et al. 2009; Hart 2008).

In the case of abatement effort too, the literature is inconclusive. Whether abatement efforts should be delayed into the distant future, or whether they should be undertaken in the near term rather than postponed, critically depends on the form of technological change, i.e., R\&D or learning-by-doing. For R\&D-based ITC, delaying abatement efforts seems to be an optimal strategy (Manne and Richels 1997) because of the reduction in the marginal abatement cost resulting from greater investment in $\mathrm{R} \& \mathrm{D}$. The direction of the path of abatement is however ambiguous for learning-by-doing-based ITC because of two countervailing forces (Goulder and Mathai 2000; Manne and Richels 2004). On the one hand, cost reductions through learning provide an incentive to undertake abatement efforts earlier. On the other hand, abatement efforts could increase over time because, in the presence of learning-by-doing, it may be optimal to postpone abatement effort given the firm will benefit from lower costs in the future. Which of these two forces dominates cannot be determined a priori.

Environmental policies that induce delayed abatement as described above are potentially costly from a social point of view given the likely path dependency in the direction of technological change. For instance both Acemoglu et al. (2012a) and Kalkuhl et al. (2012) show that firms specialized in dirty technology find it more profitable to continue to innovate in dirty technology. As a result, such firms become locked in the carbon-intensive technology because they have invested so massively in it that transitioning out of this technology becomes 
too costly. Thus, although clean technologies may be welfare-enhancing, their deployment could be stifled because the costs of switching to such technologies are prohibitively high. In their recent contribution, Aghion et al. (2016) provide empirical evidence from the auto industry supporting these theoretical results. They find that firms' innovation decision is path dependent in that it depends on their own innovation history. In such a case, imposing increased levels of carbon tax helps direct innovation towards clean technologies. Developing models that incorporate the possibility of path dependence is therefore crucial to reflect the exact costs and benefits of climate policy.

\subsection{Modelling Uncertainty in the ITC Framework}

For all these advances, most models of induced technological change often ignore the role of uncertainty in climate policy. This is surprising given the pervasive nature of uncertainty regarding climate damages and technology, let alone uncertainty regarding the ecological dimensions of the climate problem (Bretschger 2015). Notable exceptions include recent contributions (addressing the issue of uncertainty in an induced innovation framework) such as Bosetti and Tavoni (2009), Goeschl and Perino (2007), Goeschl and Perino (2009), Blanford (2009), Baker (2009), Bosetti and Drouet (2005) and Baker and Adu-Bonnah (2008).

One of the major question this emerging literature addresses is how uncertainty (primarily about technology and/or damages of climate change) affects optimal abatement and optimal R\&D investment. Although a definitive picture is yet to emerge (Baker and Shittu 2008), one fairly robust finding thus far is that the presence of uncertainty tends to make climate policies more stringent because firms are willing to incur greater costs to reduce uncertainty when they are risk averse. For instance, in analysing the effect of uncertain returns to R\&D in a backstop technology, Bosetti and Tavoni (2009) show that risk-averse investors invest more in $R \& D$ than they would in a deterministic world. This behaviour suggests indeed a hedging strategy against the eventuality that $R \& D$ has only slim chances of delivering a cost-effective backstop technology. Besides, the existence of uncertainty about the successful development of a carbon-saving technology increases economy-wide technical change and welfare because firms are less likely to postpone abatement and innovation (Löschel and Otto 2009). However, the effect of technology uncertainty on the diversification of the technology portfolio remains an open question. While uncertainty in climate change damages increases the benefits of diversification, uncertainty in technological outcomes seem to lead to less diversification in the near term. A definitive picture is yet to emerge (Baker and Shittu 2008).

\subsection{Conclusion and New Directions}

Modelling technological progress as an endogenous process that can be induced by environmental policy has brought about greater understanding and insight into the dynamic of climate policy. However, results are often not robust and hinge on the manner in which technical change is modelled. This suggests that empirical evidence regarding the representations of technical change, path dependence or uncertainty should be used more systematically to refine existing models. The importance of such an approach can be appreciated when considering the critical assumption about the substitutability versus complementarity between brown and clean technologies. Recent evidence seems to suggest that these technologies could well be complements rather than substitutes (Verdolini et al. 2016). If such empirical findings become robust or at least if it is possible to determine the conditions under which these findings are robust, this could provide useful restrictions for modelling purposes given 
the importance of this assumption in driving the modelling outcomes, as we have discussed earlier.

Incorporating uncertainty into current models more systematically, although essential, is challenging because it can substantially increase their complexity and render them intractable or at least less tractable. In doing so, one typically trades analytical tractability and clarity for a more complex and accurate reality. For this reason, numerical simulation models have been particularly useful to analyze the dynamics and incidence of climate policies under uncertainty (Bretschger 2015). The downside of those simulation models is that they do not easily lend themselves to a clear understanding of the factors that drive differing results. To gain further insights about the central mechanisms at work, developing climate economic models that provide thorough solutions for future growth and optimum climate policy including all aspects of uncertainty remains particularly important (Bretschger 2015).

\section{Empirical Evidence on Environmental Innovation and Diffusion: Where do We Stand?}

The last two decades have also witnessed a flourishing empirical literature on environmental innovation, mainly due to significant advances in the metrics and measurement of technological change. We start our review by a discussion of the data available for measuring the various steps of technological change (Sect. 3.1) and continue with a discussion of some knowledge gaps that we think are worth addressing in future work (Sects. 3.2-3.4).

\subsection{Metrics}

Since the pioneering work of Griliches (1990), economists have been concerned with how to measure valuable improvements in technology and environmental economists with identifying and measuring progress in technologies that lead to significant improvements of the environment.

The first approach of measuring R\&D inputs, such as R\&D investments in environmental technologies, has proved challenging, with cross-country data (e.g. GBAORD) being too generic and firm-level surveys being too scarce and difficult to harmonize across countries (OECD 2015; Rennings and Rexhäuser 2011; Lanoie et al. 2011). Future developments in innovation surveys are nonetheless worth following, in particular as the coverage is extended to developing countries.

By contrast, measuring innovation output, such as scientific publications and patents in particular, has proved much easier and most of the recent advances in empirical work is due to the increasing availability of patent data. Sizeable progress has been made in identifying relevant classification codes and a large set of technologies has now been identified, ranging from electricity generation, pollution control, transportation, buildings, and some adaptation technologies (Dechezlepretre et al. 2011; Popp 2002; Johnstone et al. 2010; Noailly 2012; Conway et al. 2015). Accessing and searching patent databases has become easier over the years, as new methodologies now cover the entire population of patents and researchers have become familiar with the limits and advantages of working with patent data (Hascic and Migotto 2015). Most recent and promising work in the area of environmental patents exploits the possibility to link the innovation activities of firms to other types of microdata, such as firms' financial data or firms' inspection status (Dechezlepretre and Calel 2016; Noailly and Smeets 2015; Klemetsen et al. 2016). Beside patents, another approach to measure innovation output looks at bibliometric data. Popp (2016) examines for instance publication counts in 
solar, wind, biofuels and energy efficiency. Although scientific advances embodied in publications may reflect more basic research than patent data, bibliometric data on environmental technologies have been so far largely unexploited and could lead to new research questions.

As invention and innovation are only the initial steps of technological change, other metrics are needed to measure the actual adoption and diffusion of technologies. Here again, a large body of empirical research has focused on exploiting information from patents. The literature has measured cross-country technology transfers through (i) multiple patent filings across countries (Dekker et al. 2012; Dechezlepretre et al. 2013) ${ }^{1}$ or (ii) the geography of patent citations (Jaffe and Trajtenberg 1999; Wu and Mathews 2012). More recent developments exploit disaggregated information on the geographic location of inventors as extracted from patent inventors' addresses to examine the global collaboration of co-invention teams (Hascic et al. 2012a; Noailly and Ryfisch 2015; Cantner et al. 2016; Kerr and Kerr 2015). As new patent datasets make it increasingly possible to uniquely identify inventors, a future avenue of research is to investigate how the diffusion of environmental technologies operates through the channel of the mobility of scientific personnel (Luo et al. 2013; Akcigit et al. 2016).

Beside these promising developments, patents data are ill-suited to study one of the most pressing environmental concern which is the question of technology transfers of environmental technologies to developing countries. Today, technological developments are highly concentrated in developed countries, in particular in Japan, Germany and the US, while the African continent for instance only account for $0.4 \%$ of all global environmental patents (Hascic et al. 2012). ${ }^{2}$ Due to the incremental or adaptive nature of innovation in the developing world, the lack of innovation abilities and the large share of small and medium enterprises, developing countries often score low on patent indicators. A few papers have analysed environmental technology transfers via the Clean Development Mechanisms (CDMs), but CDMs cover only a few sectors and the results from these studies remain mainly anecdotal (Popp 2011). In the growth and development literature, technology transfers to developing countries have traditionally been measured by trade and FDI data (Keller 2004). Yet, building these types of indicators for environmental goods and services present important challenges as standard sectoral codes (ISIC, NACE; NAICS) do not lend themselves to a breakdown of commodity of product classification representing environmental technologies except in very specific areas (Sawhney and Kahn 2011). One potential avenue for future work could be to exploit recently developed concordance tables that make a link between patents and sectoral classifications (Lybbert and Zolas 2014; Wurlod and Noailly 2016) as this can prove useful to identify sectors - and thus trade data - that are most likely to embody environmental technical change. Overall, measuring the diffusion of environmental technologies would be greatly facilitated by the availability of detailed sales data, some of which are slowly becoming available. For now, some papers have used installed capacity to measure diffusion in renewable energy at the country level (Popp et al. 2011), while in the automobile industry some authors have used model-level sales, including characteristics on fuel-efficiency or weight (Howell 2016).

\footnotetext{
1 The underlying ideas is that if a firm files a patent abroad it is an indication that the firm has the intention to use the technology in this country and the technology is thus transferred to the local host country. There is evidence that patents can be used as a measure of transfer as applying for a patent is costly, both in terms of procedures and in terms of administrative costs and fees associated with the filing procedure and these costs matter when deciding to protect an invention in multiple markets, so inventors are likely to only patent in another market when there is a potential for commercialization. Yet, this indicator is subject to controversies as patents filings abroad can also be used as a strategic tool to block products or competitors in international markets (Cohen et al. 2000).

2 With South Africa accounting for $84 \%$ of all African patents.
} 


\subsection{Policy Incentives for Environmental Innovation and Diffusion}

As discussed in Sect. 2, a large body of theoretical work has been concerned with optimal policies for encouraging environmental innovations, leading to a consensus on the need to combine instruments from both environmental policy (with a preference for market-based approach such as carbon pricing) and technology policy (such as research subsidy) (Acemoglu et al. 2012a). Empirical evidence over the last two decades has largely confirmed that environmental policies are effective in providing incentives to develop environmental technologies (see Popp et al. 2009 for a review of this literature). Several studies have looked at the role of some form of carbon pricing on environmental innovation (Popp 2002; Dechezlepretre and Calel 2016). Johnstone et al. (2010) find that price-based policies, such as feed-in tariffs, can effectively increase innovative activities in the more costly renewable technologies, such as solar power. Other studies have looked at the role of direct regulation and have found performance standards to be also effective to stimulate environmental innovation and diffusion (Popp 2006; Dekker et al. 2012; Lee et al. 2011; Noailly 2012; Vollebergh and Werf 2014; Dechezlepretre et al. 2015).

In line with theoretical questions, this work on policy evaluation could be extended in three fruitful directions. First, while most of the studies have focused on the stringency of environmental regulation, there is a need for more insights on the specific design of public policies. Hascic et al. (2010) find for instance that uncertain and unstable environmental policy can serve as a brake on innovation. The role of policy (in)stability on investments in clean energy technologies has been mainly studied in the real-option framework (Merton 1998) and simulations models of energy markets generally predict a negative relationship between policy uncertainty and clean investments (Yang et al. 2008). Developing new methodologies to measure the complexity and uncertainty of environmental policies (Baker et al. 2016; Botta and Kozluk 2014) could bring new insights on how these aspects impact technological change.

A second avenue for future work is to investigate in more detail the role of technology policy on environmental innovation. Theoretical work emphasizes the need to complement environmental policy with instruments from technology policy, such as research subsidies. Yet, little is known empirically on the effectiveness of various technology policy instruments, such as targeted innovation prizes or R\&D tax credits, and most studies only focus on the impact of government energy R\&D spending on environmental innovation (Popp 2016). The lack of empirical evidence is also due to the fact that most policies have so far focused on technology deployment rather than R\&D.

Finally, we need to better understand which policy instruments are effective in the context of developing countries. We have limited knowledge about how public policies can encourage 'adaptive' R\&D. Such policies might need to focus more on local content requirement or applied research than on encouraging radical innovation. In addition, developing countries face several challenges such as corruption and compliance issues, which likely affect the effectiveness of regulations. In addition, while there is some evidence that multinational firms transfer technologies to their foreign affiliates in the developing world (Branstetter et al. 2006), more research should investigate the impact of local environmental policies on the adoption of foreign technologies. Recent evidence by Howell (2016) shows for instance that the stringent 2009 fuel-efficiency standards implemented in China were not effective in transferring foreign technologies to domestic producers in the automobile industry. Joint ventures mandates resulted in lower incentives for technology upgrading by Chinese producers, as competing with foreign partner would cannibalize the domestic firm's share of foreign brands profits. As a result, domestic producers did not acquire foreign technologies 
on fuel-efficient powertrain and chose instead to produce small, light-weight and low-quality cars to meet the standards.

\subsection{Firm Dynamics}

Another avenue of research in empirical studies of innovation, diffusion and the environment relates to firm dynamics and market structure. Achieving a technological transition implies a shift from current technologies (e.g. fossil-fuel energy) that are mainly developed by large incumbent firms, to often radically new types of technologies (e.g. renewable energy), which may be developed by new entrants challenging the established organisation and structure of the market (van der Ploeg 2016; Noailly and Smeets 2015). The innovation and growth literature provides useful insights to understand how technological transitions can take place via innovation from heterogeneous firms (Klette and Kortum 2004; Acemoglu and Cao 2010) ${ }^{3}$ and documents some key stylized facts about innovating firms, namely: $(i)$ the distribution of R\&D intensity among firms tend to be highly skewed; (ii) large established firms innovate a lot but tend to focus on improving existing technologies (Cohen and Klepper 1992; Akcigit and Kerr 2010); (iii) small firms and new entrants are often believed to be the source of more major and radical innovations than large firms (Akcigit 2011; Kamien and Schwartz 1975). Applying these insights to the electricity generation sector, Noailly and Smeets (2015) find that the reduction in the aggregate technology gap between fossil-fuel and renewable patenting activities observed in recent years has been mainly induced by increased entry of small firms specialized in renewable innovation. Large incumbent firms instead have remained locked-in in fossil-fuel technologies, due to path-dependent processes in innovation. Regarding technology adoption, Linn (2008) also finds that entrants have greater flexibility in adopting new energy-efficient technologies than incumbents. More research is needed to understand the forces that shape firm dynamics and create entry, whether these are new technological opportunities, new market demand or easier access to external finance. In addition, the findings that new entrants are more likely to innovate and adopt new technologies may have implications for developing countries where we know that firm dynamics tend to be weak (Akcigit et al. 2014). Finally, this is not to say that the role of incumbents should be ignored: incumbents may be better able to use the existing knowledge and may play a key role in adopting and scaling up new technologies due to their active role in mergers and acquisitions. The question is more about the right balance of competition between incumbents and entrants.

In general, there are reasons to believe that firm dynamics may be different for environmental technologies than for other technologies. There is for instance some preliminary evidence that entry could be more difficult for firms innovating in renewable technologies as they tend to be more financially constrained than firms innovating in fossil-fuel technologies (Noailly and Smeets 2016), other things being equal. Theoretically, investments in clean technologies tend to have an unattractive risk/return profile compared to other types of technologies mainly because these technologies are heavily dependent on public support - and the risk that policies supporting clean technologies are subject to unexpected and sudden changes makes it particularly challenging for investors (Nanda et al. 2015; Criscuolo and Menon 2015).

3 See Acemoglu et al. (2012b) for a first application to clean technology transition. 


\subsection{Impact of Innovation and Diffusion}

Finally, a strand of empirical work has been concerned with measuring the outcomes of technological progress in environmental technologies. Clean technologies can provide benefits to various segments of society, in terms of reduced carbon emissions, energy-efficiency (Popp 2001; Wurlod and Noailly 2016), improved health, but also possibly lower costs of resource use, higher productivity and economic growth. It is important to quantify and understand further the value of these impacts and future work should aim to enhance our knowledge on these issues.

First, we have little understanding on the impact of environmental R\&D on cost reductions in technologies. Such cost reductions are important to achieve a sizeable scale of technology adoption. Past research has focused on learning-by-doing to explain technology cost reduction, namely learning through experience of production. Yet, Nemet (2006) finds for instance that learning from experience only weakly explains the decline in capital costs of solar PV modules, which was reduced by a factor of nearly 100 since the 1950 s. Instead, the effect of knowledge acquired by R\&D on technology costs may be substantial.

Second, the ability of environmental innovations to improve firms' profitability has been examined in the literature on the Porter hypothesis (Porter and Linde 1995; Lanoie et al. 2011; Kozluk and Zipperer 2015), but much of the empirical work on the strong version of the hypothesis - innovation productivity gains can offset the costs of regulation-remains inconclusive. More studies are needed to complement this line of research. Since the link between environmental technologies (and thus costly policies), productivity and economic growth is a critical question for policymakers, empirics can greatly serve theory on these issues.

Subsequently, as the welfare impact of environmental technologies depends on the relative size of the social benefits coming from knowledge spillovers, future work should continue to explore how spillovers from clean technologies differ from other technologies. Using patent citations, Dechezlepretre et al. (2014) find that clean technologies generate larger knowledge spillovers, i.e. have broader applications through society, than dirty technologies. The authors also find that spillovers from clean technologies are more economically valuable as measured by firms' stock value. This is important as it implies that directed technical change towards clean technologies could help offset the costs of climate change and thereby encourage economic growth.

\section{Conclusion}

This brief article discussed some of the current trends in the field of technological change and the environment and identified several avenues of research and new directions. This list of research priorities is, however, by no means comprehensive. In September 2015, we organized a conference entitled "Economics of innovation, diffusion, growth and the environment" held at the Royal Society of Arts in London ${ }^{4}$ combining theoretical and empirical work with the objective of producing new models and new data to advance current understanding of the economics of growth and the environment. In this special issue, a selection of papers presented at the conference and reflecting on the issues discussed here have been assembled. We thereby hope to provide readers with a snapshot of recent work that will inspire future

$\overline{{ }^{4} \text { See http://www.lse.ac.uk/GranthamInstitute/event/innovationconference/. }}$ 
work-in which the theoretical foundations of policy-relevant questions will continue to be enriched by data-intensive empirical work.

\section{References}

Acemoglu D, Cao D (2010) Innovation by entrants and incumbents. MIT Working Paper Series 10-12

Acemoglu D, Aghion P, Bursztyn L, Hemous D (2012a) The environment and directed technical change. Am Econ Rev 102(1):131-166

Acemoglu D, Akcigit U, Hanley D, Kerr W (2012b) Transition to clean technology. MIT, Mimeo

Aghion P, Howitt P (1992) A model of growth through creative destruction. Econometrica 60(2):323-351

Aghion P, Dechezlepretre A, Hemous D, Martin R, Reenen JV (2016) Carbon taxes, path dependency, and directed technical change: evidence from the auto industry. J Polit Econ 124(1):1-51

Akcigit U (2011) Firm size, innovation dynamics and growth. University of Pennsylvania, Working Paper

Akcigit U, Kerr W (2010) Growth through heterogeneous innovations. PIER Working Paper 10-035

Akcigit U, Alp H, Peters M (2014) Lack of selection and imperfect managerial contracts: Firm dynamics in developing countries. University of Pennsylvania, Working Paper

Akcigit U, Baslandze S, Stantcheva S (2016) Taxation and the international mobility of inventors. Am Econ Rev 106(10):2930-2981

Aronsson T, Backlund K, Sahlén L (2010) Technology transfers and the clean development mechanism in a North-South general equilibrium model. Resour Energy Econ 32(3):292-309

Baker E (2009) Optimal policy under uncertainty and learning about climate change: a stochastic dominance approach. J Public Econ Theory 11(5):721-747

Baker E, Adu-Bonnah K (2008) Investment in risky R\&D programs in the face of climate uncertainty. Energy Econ 30(2):465-486

Baker E, Shittu E (2008) Uncertainty and endogenous technical change in climate policy models. Energy Econ 30(6):2817-2828

Baker SR, Bloom N, Davis SJ (2016) Measuring economic policy uncertainty. NBER Working Paper w21633

Blanford GJ (2009) R\&D investment strategy for climate change. Energy Econ 31:S27-S36

Bosetti V, Drouet L, (2005) Accounting for uncertainty affecting technical change in an economic-climate model. FEEM Working Paper

Bosetti V, Tavoni M (2009) Uncertain R\&D, backstop technology and GHGs stabilization. Energy Econ 31:S18-S26

Botta E, Kozluk T (2014) Measuring environmental policy stringency in OECD countries. OECD Working Paper

Branstetter LG, Fisman R, Foley CF (2006) Do stronger intellectual property rights increase international technology transfer? Empirical evidence from U.S. firm-level panel data. Q J Econ 121(1):321-349

Brechet T, Meunier G (2014) Are clean technology and environmental quality conflicting policy goals? Resour Energy Econ 38:61-83

Bretschger L (2015) Greening economy, graying society. CER-ETH Press, Zurich

Buonanno P, Carraro C, Galeotti M (2003) Endogenous induced technical change and the costs of Kyoto. Resour Energy Econ 25(1): 11-34

Cantner U, Graf H, Herrmann J, Kalthaus M (2016) Inventor networks in renewable energies: the influence of the policy mix in Germany. Res Policy 45(6):1165-1184

Cohen W, Klepper S (1992) The anatomy of industry R\&D industry distribution. Am Econ Rev 82:773-799

Cohen M, Nelson R, Walsh J (2000) Protecting their intellectual assets: appropriability conditions and why U.S. manufacturing firms patent (or not). NBER Working Paper w7552

Conway D, Dechezlepretre A, Johnstone N, Hascic I (2015) Invention and diffusion of water supply and water efficiency technologies: insights from a global patent database. Working Paper 196, Grantham Research Institute on Climate Change and the Environment

Criscuolo C, Menon C (2015) Environmental policies and risk finance in the green sector: cross-country evidence. Energy Policy 83:38-56

Dasgupta P, Heal G (1974) The optimal depletion of exhaustible resources. Rev Econ Stud 41:3-28

Dechezlepretre A, Calel R (2016) Environmental policy and directed technical change: evidence from the European carbon market. Rev Econ Stat 98(1):173-191

Dechezlepretre A, Glachant M, Hascic I, Johnstone N, Meniere Y (2011) Invention and transfer of climate change mitigation technologies: a global analysis. Rev Environ Econ Policy 1(5):109-130

Dechezlepretre A, Glachant M, Meniere Y (2013) What drives the international transfer of climate change mitigation technologies? Empirical evidence from patent data. Environ Resour Econ 54(2):161-178 
Dechezlepretre A, Martin R, Mohnen M (2014) Knowledge spillovers from clean and dirty technologies. CEP discussion paper, Centre for Economic Performance LSE

Dechezlepretre A, Neumayer E, Perkins R (2015) Environmental regulation and the cross-border diffusion of new technology: evidence from automobile patents. Res Policy 44(1):244-257

Dekker T, de Vries F, Vollebergh H, Withagen C (2012) Inciting protocols. J Environ Econ Manag 64(1):45-67

Eichner T, Pethig R (2011) Carbon leakage, the green paradox, and perfect future markets. Int Econ Rev 52(3):767-805

Fischer C, Preonas L (2010) Combining policies for renewable energy: Is the whole less than the sum of its parts? Int Rev Environ Resour Econ 4:51-92

Gerlagh R, Kuik O (2014) Spill or leak? Carbon leakage with international technology spillovers: a CGE analysis. Energy Econ 45:381-388

Gerlagh R, Kverndokk S, Rosendahl KE (2009) Optimal timing of climate change policy: interaction between carbon taxes and innovation externalities. Environ Resour Econ 43(3):369-390

Gillingham K, Newell RG, Pizer WA (2008) Modeling endogenous technological change for climate policy analysis. Energy Econ 30(6):2734-2753

Goeschl T, Perino G (2007) Innovation without magic bullets: stock pollution and R\&D sequences. J Environ Econ Manag 54(2):146-161

Goeschl T, Perino G (2009) On backstops and boomerangs: environmental R\&D under technological uncertainty. Energy Econ 31(5):800-809

Goulder LH, Mathai K (2000) Optimal CO2 abatement in the presence of induced technological change. J Environ Econ Manag 39(1):1-38

Goulder LH, Schneider SH (1999) Induced technological change and the attractiveness of CO2 abatement policies. Resour Energy Econ 21(3):211-253

Griliches Z (1990) Patent statistics as economic indicators: a survey. J Econ Lit 28(4):1661-1707

Grossman GM, Helpman E (1991) Quality ladders in the theory of growth. Rev Econ Stud 58(1):43-61

Grubb M (2000) Economic dimensions of technological and global responses to the Kyoto protocol. J Econ Stud 27(1/2):111-125

Grubb M, Chapuis T, Duong MH (1995) The economics of changing course: implications of adaptability and inertia for optimal climate policy. Energy Policy 23(4):417-431

Hart R (2008) The timing of taxes on CO2 emissions when technological change is endogenous. J Environ Econ Manag 55(2):194-212

Hascic I, Migotto M (2015) Measuring environmental innovation using patent data. OECD Environment Working Paper

Hascic I, Johnstone N, Kalamova M (2010) Environmental policy design characteristics and technological innovation. OECD Environment Working Paper

Hascic I, Johnstone N, Kahrobaie N (2012a) International technology agreements for climate change: analysis based on co-invention data. OECD Environment Working Paper

Hascic I, Silva J, Johnstone N (2012b) Climate mitigation and adaptation in Africa: evidence from patent data. OECD Environment Working Paper

Howell S (2016) Incentives to invest in new technology: the effect of fuel economy standards on China's automakers. NYU Stern Working Paper

Hübler M, Baumstark L, Leimbach M, Edenhofer O, Bauer N (2012) An integrated assessment model with endogenous growth. Ecol Econ 83:118-131

Jacoby HD, Reilly JM, McFarland JR, Paltsev S (2006) Technology and technical change in the MIT EPPA model. Energy Econ 28(5):610-631

Jaffe AB, Trajtenberg M (1999) International knowledge flows: evidence from patent citations. Econ Innov New Technol 8(1-2):105-136

Jaffe AB, Newell RG, Stavins RN (2003) Technological change and the environment (Chapter 11). In: Mler K-G, Vincent JR (eds) Handbook of environmental economics, vol 1. Elsevier, Amsterdam, pp 461-516

Johnstone N, Hascic I, Popp D (2010) Renewable energy policies and technological innovation: evidence based on patent counts. Environ Resour Econ 45(1):133-155

Kalkuhl M, Edenhofer O, Lessmann K (2012) Learning or lock-in: optimal technology policies to support mitigation. Resour Energy Econ 34(1):1-23

Kamien M, Schwartz N (1975) Market structure and innovation. J Econ Lit 13(1):1-37

Keller W (2004) International technology diffusion. J Econ Lit 42(3):752-782

Kerr S, Kerr W (2015) Global collaborative patents. NBER Working Paper w21735

Klemetsen M, Bye B, Raknerud A (2016) Can direct regulations spur innovations in environmental technologies? A study on firm-level patenting. Scand J Econ (forthcoming)

Klette J, Kortum S (2004) Innovating firms and aggregate innovation. J Polit Econ 112(5):986-1018 
Kozluk T (2014) Zipperer V (2015) Environmental policies and productivity growth. OECD J Econ Stud $1: 155-185$

Lanoie P, Laurent-Lucchetti J, Johnstone N, Ambec S (2011) Environmental policy, innovation and performance : new insights on the porter hypothesis. J Econ Manag Strategy 20(3):803-842

Lee J, Veloso F, Hounshell D (2011) Linking induced technological change and environment regulation: evidence from patenting in the US auto industry. Res Policy 40(9):1240-1252

Linn J (2008) Energy prices and the adoption of energy-saving technology. Econ J 118(533):1986-2012

Löschel A, Otto VM (2009) Technological uncertainty and cost effectiveness of CO2 emission reduction. Energy Econ 31:S4-S17

Luo S, Lovely ME, Popp D (2013) Intellectual returnees as drivers of indigenous innovation: evidence from the Chinese photovoltaic industry. NBER Working Paper w19518

Lybbert T, Zolas NJ (2014) Getting patents and economic data to speak to each other: an algorithmic links with probabilities approach for joint analyse of patenting and economic activity. Res Policy 48(3):530-542

Manne A, Richels R (1997) On stabilizing CO2 concentrations-cost-effective emission reduction strategies. Environ Model Assess 2(4):251-265

Manne A, Richels R (2004) The impact of learning-by-doing on the timing and costs of CO2 abatement. Energy Econ 26(4):603-619

Meadows DH, Meadows, DL, Randers J, Behrens WW (1972) The limits to growth. New York 102

Merton RC (1998) Applications of option-pricing theory: twenty-five years later. Am Econ Rev 88(3):323-349

Metz B, Davidson O, Bosch P, Dave R, Meyer L (2007) Climate change 2007: mitigation: contribution of working group III to the fourth assessment report of the intergovernmental panel on climate change: summary for policymakers and technical summary. Cambridge University Press

Nanda R, Younge K, Fleming L (2015) Innovation and entrepreneurship in renewable energy. In: Jaffe A, Jones B (eds) The changing frontier: rethinking science and innovation policy. University of Chicago Press, Chicago, p 199

Nemet GF (2006) Beyond the learning curve: factors influencing cost reductions in photovoltaics. Energy Policy 34(17):3218-3232

Noailly J (2012) Improving the energy efficiency of buildings: the impact of environmental policy on technological innovation. Energy Econ 34:795-806

Noailly J, Ryfisch D (2015) Multinational firms and the internationalization of green R\&D: a review of the evidence and policy implications. Energy Policy 83(C):218-228

Noailly J, Smeets R (2015) Directing technical change from fossil-fuel to renewable energy innovation: an application using firm-level data. J Environ Econ Manag 72(C):15-37

Noailly J, Smeets R (2016) Financing energy innovation: the role of financing constraints for directed technical change from fossil-fuel to renewable innovation. Working paper, European Investment Bank (forthcoming)

Nordhaus WD (2002) Modeling induced innovation in climate-change policy (chapter 8). In: Grubler A, Nakicenovic N, Nordhaus W (eds) Technological change and the environment, vol 9. RFF and IIASA, Laxenburg, pp 259-290

Nordhaus W (2011) Designing a friendly space for technological change to slow global warming. Energy Econ 33(4):665-673

Nordhaus WD, Stavins RN (1992) Weitzman ML (1992) Lethal model 2: the limits to growth revisited. Brook Pap Econ Act 2:1-59

OECD (2015) Main science and technology indicators. OECD Publishing

Perino G, Requate T (2012) Does more stringent environmental regulation induce or reduce technology adoption? When the rate of technology adoption is inverted U-shaped. J Environ Econ Manag 64(3):456467

Popp DC (2001) The effect of new technology on energy consumption. Resour Energy Econ 23(3):215-239

Popp D (2002) Induced innovation and energy prices. Am Econ Rev 92(1):160-180

Popp D (2004) ENTICE: endogenous technological change in the DICE model of global warming. J Environ Econ Manag 48(1):742-768

Popp D (2006a) ENTICE-BR: the effects of backstop technology R\&D on climate policy models. Energy Econ 28(2):188-222

Popp D (2006b) Innovation in climate policy models: implementing lessons from the economics of R\&D. Energy Econ 28(5):596-609

Popp D (2006c) International innovation and diffusion of air pollution control technologies: the effects of NOx and SO2 regulations in the US, Japan and Germany. J Environ Econ Manag 51:46-71

Popp D (2006d) R\&D subsidies and climate policy: Is there a free lunch? Clim Change 77(3-4):311-341

Popp D (2011) International technology transfer, climate change, and the clean development mechanism. Rev Environ Econ Policy 5(1):131-152 
Popp D (2015) Climate-friendly technological change for developing countries. In: Bernard L, Semmler W (eds) The oxford handbook of the macroeconomics of global warming. Oxford University Press, Oxford, pp 321-348

Popp D (2016) Economic analysis of scientific publications and implications for energy research and development. Nat Energy 1

Popp D, Newell R, Jaffe A (2009) Energy, the environment and technological change. NBER Working Paper 14832

Popp D, Hascic I, Mehdi N (2011) Technology and the diffusion of renewable energy. Energy Econ 33(4):648662

Porter M, van der Linde C (1995) Toward a new conception of the environment-competitiveness relationship. J Econ Perspect 9:97-118

Rennings K, Rexhäuser S (2011) Long-term impacts of environmental policy and eco-innovative activities of firms. Int J Technol Policy Manag 11(3-4):274-290

Romer P (1990) Endogenous technological change. J Polit Econ 98(5):71-102

Sawhney A, Kahn M (2011) Understanding cross-national trends in hightech renewable power equipment exports to the United States. NBER Working Paper w17217

Sinn H-W (2008) Public policies against global warming: a supply side approach. Int Tax Public Finance 15(4):360-394

Smulders S, De Nooij M (2003) The impact of energy conservation on technology and economic growth. Resour Energy Econ 25(1):59-79

Smulders S, Di Maria C (2012) The cost of environmental policy under induced technical change. CESifo Working Paper

Stern NH, Peters S, Bakhshi V, Bowen A, Cameron C, Catovsky S, Crane D, Cruickshank S, Dietz S, Edmonson N (2006) Stern review: the economics of climate change, vol 30. Cambridge University Press, Cambridge

Sue Wing I (2001) Induced technical change in computable general equilibrium models for climate-change policy analysis. Ph.D. thesis, Massachusetts Institute of Technology

Sue Wing I (2003) Induced technical change and the cost of climate policy. Joint Program on the Science and Policy of Global Change, Report no 112

van der Ploeg F (2016) Fossil fuel producers under threat. Oxford Rev Econ Policy 32(2):206-222

van der Ploeg F, Withagen C (2012) Is there really a green paradox? J Environ Econ Manag 64(3):342-363

Verdolini E, Vona F, Popp D (2016) Bridging the gap: Do fast reacting fossil technologies facilitate renewable energy diffusion? NBER Working Paper w22454

Vollebergh HRJ, van der Werf E (2014) The role of standards in eco-innovation: lessons for policymakers. Rev Environ Econ Policy 8(2):230-248

Wu C, Mathews J (2012) Knowledge flows in the solar photovoltaic industry: Insights from patenting by Taiwan, Korea, and China. Res Policy 41(3):524-540

Wurlod JD, Noailly J (2016) The impact of green innovation on energy intensity: an empirical analysis for 14 industrial sectors in OECD countries. CIES Research Papers 42, Graduate Institute of International and Development Studies

Yang M, Blyth W, Bradley R, Bunn D, Clarke C, Wilson T (2008) Evaluating the power investment options with uncertainty in climate policy. Energy Econ 30(4):1933-1950 